Rev. 0

\title{
MEASUREMENT OF SPECIFIC HEAT CAPACITY OF SALTSTONE
}

\author{
J. R. Harbour and V. J. Williams
}

Savannah River National Laboratory

September 2008

Process Science and Engineering Savannah River National Laboratory Aiken, SC 29808

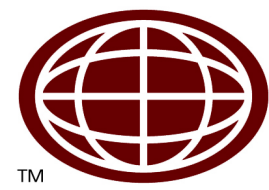




\section{DISCLAIMER}

This work was prepared under an agreement with and funded by the U.S. Government. Neither the U.S. Government or its employees, nor any of its contractors, subcontractors or their employees, makes any express or implied: 1. warranty or assumes any legal liability for the accuracy, completeness, or for the use or results of such use of any information, product, or process disclosed; or 2. representation that such use or results of such use would not infringe privately owned rights; or 3. endorsement or recommendation of any specifically identified commercial product, process, or service. Any views and opinions of authors expressed in this work do not necessarily state or reflect those of the United States Government, or its contractors, or subcontractors.

\section{Printed in the United States of America \\ Prepared For U.S. Department of Energy}


Key Words: Heat of Hydration Simple Law of Mixtures Thermal Conductivity

Retention: Permanent

\title{
MEASUREMENT OF SPECIFIC HEAT CAPACITY OF SALTSTONE
}

\author{
J. R. Harbour and V. J. Williams
}

Savannah River National Laboratory

September 2008

Process Science and Engineering Savannah River National Laboratory Aiken, SC 29808

Prepared for the U.S. Department of Energy Under Contract Number DE-AC09-08SR22470

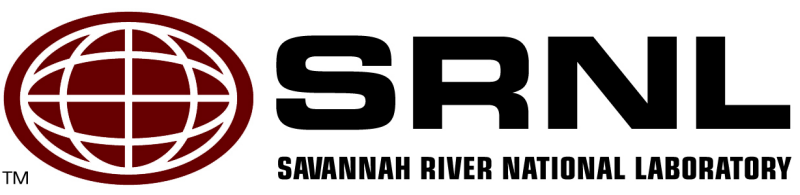




\section{REVIEWS AND APPROVALS}

\section{AUTHORS:}

J. R. Harbour, SRNL, Engineering Process Development

Date

V. J. Williams, SRNL, Engineering Process Development

Date

\section{TECHNICAL REVIEWERS:}

A. D. Cozzi, SRNL, Engineering Process Development

Date

\section{APPROVERS}

A. B. Barnes, SRNL, Manager, Engineering Process Development

Date

J. C. Griffin SRNL, Manager, E\&CPT Research Programs

Date

J. E. Occhipinti, Manger, Waste Solidification Engineering

Date 


\section{EXECUTIVE SUMMARY}

One of the goals of the Saltstone variability study is to identify (and quantify the impact of) the operational and compositional variables that control or influence the important processing and performance properties of Saltstone grout mixtures. The heat capacity of the Saltstone waste form is one of the important properties of Saltstone mixes that was last measured at SRNL in 1997. It is therefore important to develop a core competency for rapid and accurate analysis of the specific heat capacity of the Saltstone mixes in order to quantify the impact of compositional and operational variations on this property as part of the variability study.

The heat capacity, coupled with the heat of hydration data obtained from isothermal calorimetry for a given Saltstone mix, can be used to predict the maximum temperature increase in the cells within the vaults of the Saltstone Disposal Facility (SDF). The temperature increase controls the processing rate and the pour schedule. The maximum temperature is also important to the performance properties of the Saltstone. For example, in mass pours of concrete or grout of which Saltstone is an example, the maximum temperature increase and the maximum temperature difference (between the surface and the hottest location) are controlled to ensure durability of the product and prevent or limit the cracking caused by the thermal gradients produced during curing.

This report details the development and implementation of a method for the measurement of the heat capacities of Saltstone mixes as well as the heat capacities of the cementitious materials of the premix and the simulated salt solutions used to batch the mixes. The developed method utilizes the TAM Air isothermal calorimeter and takes advantage of the sophisticated heat flow measurement capabilities of the instrument. Standards and reference materials were identified and used to validate the procedure and ensure accuracy of testing.

Heat capacities of Saltstone mixes were $\sim 55 \%$ higher than the previous measurement of specific heat capacity on a reference Saltstone mix in 1997. Values of mixes prepared using Deliquification, Dissolution and Adjustment (DDA), Modular Caustic Side Solvent Extraction Unit (MCU) and Salt Waste Processing Facility (SWPF) simulants and premix at $0.60 \mathrm{w} / \mathrm{cm}$ ratio were $\sim 1.95 \mathrm{~J} / \mathrm{g} /{ }^{\circ} \mathrm{C}$ and were equivalent within experimental error. The simple law of mixtures was used to predict the heat capacities of the Saltstone and the results were in excellent agreement with experimental data. This simple law of mixtures can therefore be used to predict the heat capacities of Saltstone mixes in those cases where measurements have not been made.

The time dependence of the heat capacity is important as an input to the modeling of temperature increase in Saltstone vaults. The heat capacity of a mix of MCU and premix at $0.60 \mathrm{w} / \mathrm{cm}$ ratio was measured immediately after initial mixing and then periodically up to times greater than 100 days. Within experimental error, the heat capacity did not change with time. Therefore, the modeling is not complicated by requiring a time dependent function for specific heat capacity.

The water to cementitious material $(\mathrm{w} / \mathrm{cm})$ ratio plays a key role in determining the value of the heat capacity. Both experimental and predictive values for SWPF mixes as function of the w/cm ratio were obtained and presented in this report. 
Predictions of the maximum temperatures of the Saltstone mixes were made using the heat of hydration data from previous isothermal measurements and the newly measured heat capacities for DDA, MCU and SWPF mixes. The maximum temperature increase ranged from 37 to $48^{\circ} \mathrm{C}$ for these mixes. The presence of aluminate at $0.33 \mathrm{M}$ produced a temperature increase of $68{ }^{\circ} \mathrm{C}$ which is close to the adiabatic temperature rise of $74{ }^{\circ} \mathrm{C}$ observed by Steimke and Fowler in 1997 for a mix containing $0.35 \mathrm{M}$ aluminate. Aluminum dissolution of the sludge will increase the aluminate in the DSS which in turn will result in a larger temperature increase in the Saltstone vaults during the curing period.

The initial temperature of the Saltstone mixes in the Saltstone Production Facility (SPF) can be predicted using the specific heat capacities of Decontaminated Salt Solutions (DSS), the specific heat capacities of cementitious materials, and the initial temperatures of the DSS and the premix. This initial mix temperature is dominated by the DSS temperature due to its high heat capacity relative to the cementitious materials. Therefore, controlling the initial temperature of the DSS to lower temperatures will lead to lower maximum temperatures in the vault for a given batch of Saltstone. 


\section{TABLE OF CONTENTS}

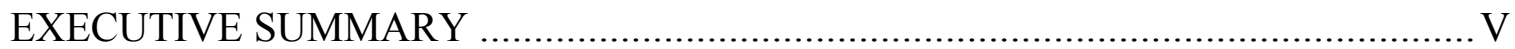

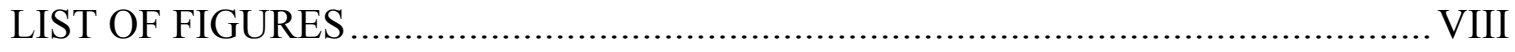

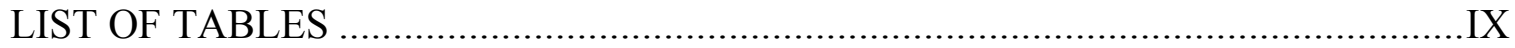

LIST OF ACRONYMS …................................................................................

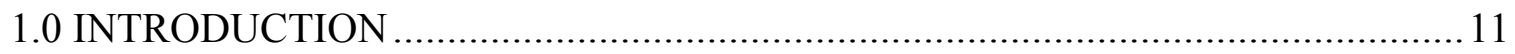

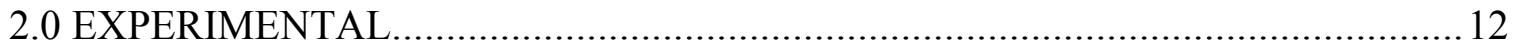

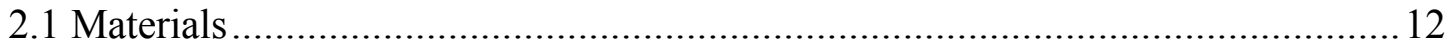

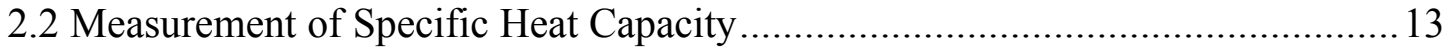

3.0 RESULTS AND DISCUSSION..................................................................... 16

3.1 Specific Heat Capacity of Saltstone Cementitious Materials and Simulants......... 16

3.2 Prediction of Specific Heat Capacity of Saltstone Mixes .................................. 17

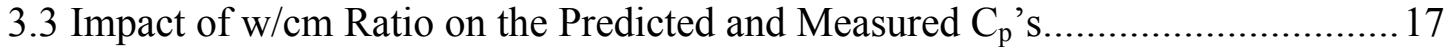

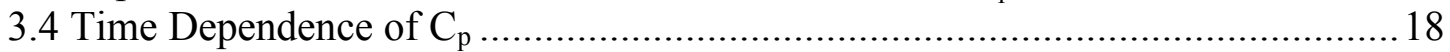

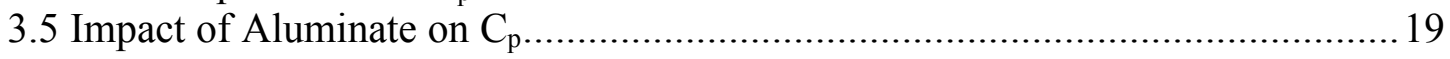

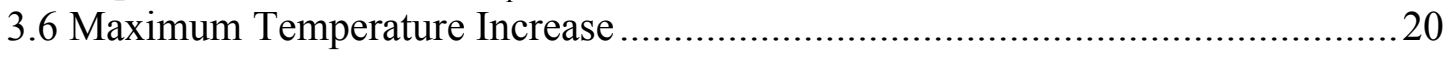

3.7 Prediction of Fresh Mix Temperature in the SPF .................................... 23

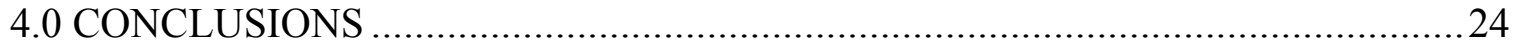

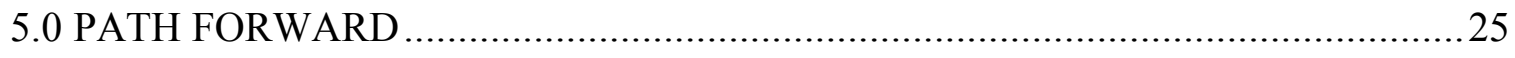

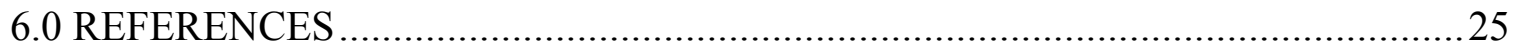




\section{LIST OF FIGURES}

Figure 2-1 Cutaway view of the twin configuration TAM Air Isothermal Calorimeter......... 13

Figure 2-2 The time dependence of heat flow and heat for $10.77 \mathrm{~g}$ of ethanol in the sample

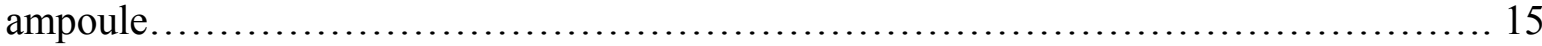

Figure 3-1 Predicted dependence of $\mathrm{Cp}$ on $\mathrm{w} / \mathrm{cm}$ ratio for SWPF mixes based on simple law of

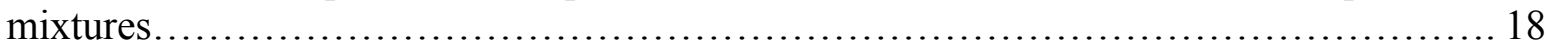

Figure 3-2 Time dependence (logarithmic) of $\mathrm{Cp}$ for an MCU mix at $0.60 \mathrm{w} / \mathrm{cm}$ ratio......... 19

Figure 3-3 Calculated maximum temperature increase of DDA/premix mix at $0.60 \mathrm{w} / \mathrm{cm}$ ratio 20

Figure 3-4 Calculated maximum temperature increase of water/OPC mix at $0.60 \mathrm{w} / \mathrm{cm}$ ratio for

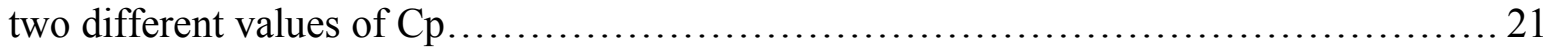

Figure 3-5 Calculated maximum temperature increase of MCU/BFS mix at $0.60 \mathrm{w} / \mathrm{cm}$ ratio using three different values for the specific heat capacity.......................... 22 


\section{LIST OF TABLES}

Table 2-1 Saltstone Cementitious Materials 13

Table 3-1 Measured Specific Heat Capacities for Saltstone Simulants and Cementitious

Materials..... 16

Table 3-2 Predicted vs. Measured $C_{p}$ for the Three Saltstone Mixes...................................... 17

Table 3-3 Predicted Vs. Measured $\mathrm{C}_{\mathrm{p}}$ for the SWPF Mix at Different w/cm Ratios ................. 17

Table 3-4 Predicted Vs. Measured $\mathrm{C}_{\mathrm{p}}$ as a Function of Aluminate Molarity .......................... 20

Table 3-5 Summary of Predicted Maximum Temperatures of Various Grout Mixes................ 22

Table 3-6 Summary of Adiabatic Temperature Measurements from Literature. 


\section{LIST OF ACRONYMS}

\begin{tabular}{|l|l|}
\hline ACTL & Aiken County Technology Laboratory \\
\hline FA & Class F Fly Ash \\
\hline BFS & Blast Furnace Slag \\
\hline C $_{p}$ & Specific Heat Capacity \\
\hline DDA & Deliquification, Dissolution and Adjustment \\
\hline DSS & Decontaminated Salt Solution \\
\hline J & Joule \\
\hline k & Thermal Conductivity \\
\hline M & Molarity \\
\hline MCU & Modular Caustic Side Solvent Extraction Unit \\
\hline Mf & Mass Fraction \\
\hline NA & Not Available \\
\hline OPC & Ordinary Portland Cement \\
\hline SDF & Saltstone Disposal Facility \\
\hline SPF & Saltstone Production Facility \\
\hline SRNL & Savannah River National Laboratory \\
\hline SRNS & Savannah River Nuclear Solutions \\
\hline SRS & Savannah River Site \\
\hline SWPF & Salt Waste Processing Facility \\
\hline TR & Trial Run \\
\hline w/cm & Water to Cementitious Material Ratio \\
\hline
\end{tabular}




\subsection{INTRODUCTION}

One of the goals of the Saltstone variability study is to identify (and quantify the impact of) the operational and compositional variables that control or influence the important processing and performance properties of Saltstone grout mixtures [1-2]. The heat capacity of the Saltstone waste form is one of the important properties of Saltstone mixes that was last measured at SRNL in 1997 [3]. It is therefore important to measure the heat capacity of Saltstone mixes using the currently projected batches for decontaminated salt solution (DSS). It is also important to develop and implement a core competency for rapid and accurate analysis of the specific heat capacity of the Saltstone mixes in order to quantify the impact of compositional and operational variations on this property as part of the variability study.

The heat capacity of a Saltstone waste form (or any material) is a quantitative measure of the amount of heat required to raise the temperature of the material. In thermodynamics, the heat capacity is defined as $\mathrm{dQ} / \mathrm{dT}$ at a given temperature and is an intensive property (i.e., mass dependent). To convert this measure to a more usable form, the specific heat capacity for a material has been defined as the amount of heat required to raise the temperature of 1 gram of the material 1 degrees $\mathrm{C}$. For example, it requires $4.184 \mathrm{~J}$ ( 1 calorie is equal to $4.184 \mathrm{~J}$ ) to raise the temperature of 1 gram of water $1^{\circ} \mathrm{C}$. In this report the term specific heat capacity will be used interchangeably with the term heat capacity and will be designated as $C_{p}$.

The heat capacity and the heat of hydration (from isothermal calorimetry) for a given Saltstone mix can be used to predict the maximum temperature increase in the cells within the vaults of the Saltstone Disposal Facility (SDF). The temperature increase controls the processing rate and the pour schedule [4]. The maximum temperature is also important to the performance properties of the Saltstone. For example, in mass pours of concrete or grout of which Saltstone is an example, the maximum temperature increase and the maximum temperature difference (between the surface and the hottest location) are controlled to ensure durability of the product and prevent or limit the cracking caused by the thermal gradients produced during curing [5].

This heat capacity has taken on increased importance recently due to the initiation of a formulation development task for improving the performance properties of Saltstone. In order to achieve improved performance, some of the grout formulations being considered will not only increase the amount of heat of hydration per gram of grout but may also change (and in most cases reduce) the heat capacity of the resultant mix. It turns out that a reduction in heat capacity leads to a larger temperature increase within the vault for a given heat of hydration, a scenario which reduces the processing rate. Consideration of all of the impacts of changes in formulation must be included in decision making prior to adopting new formulations,

This report details the development and implementation of a method for the measurement of the heat capacities of Saltstone mixes as well as the heat capacities of the cementitious materials of the premix and the simulated salt solutions used to batch the mixes. The developed method utilizes the TAM Air isothermal calorimeter [6] and takes advantage of the sophisticated heat 
flow measurement capabilities of the instrument. Standards and reference materials were identified and used to validate the procedure and ensure accuracy of testing.

The simple law of mixtures can be used to predict the specific heat capacity for the fresh Saltstone mixes. In this method, the predicted initial specific heat capacity of a Saltstone mix is given by Equation 1

$$
\mathrm{C}_{\mathrm{p}}(\text { fresh paste })=\mathrm{C}_{\mathrm{p}}(\mathrm{dss}) * \mathrm{Mf}^{\mathrm{dss}}+\mathrm{C}_{\mathrm{p}}(\mathrm{pm}) * \mathrm{Mf}^{\mathrm{pm}}
$$

where $\mathrm{Mf}^{\mathrm{dss}}$ and $\mathrm{Mf}^{\mathrm{pm}}$ are the mass fractions of the decontaminated salt solution and the premix respectively and the $\mathrm{C}_{\mathrm{p}}$ 's are specific heat capacities of the starting materials and the initial fresh mix (referred to as fresh paste). This method has been used successfully to predict the specific heat capacities for portland cement in water mixes by D. Bentz of NIST [7]. Application of this predictive method to Saltstone mixes requires as input the heat capacities of the salt solutions and the cementitious materials. These heat capacity values were obtained using the method developed and presented in this report.

Steimke measured the specific heat for the then "Reference Saltstone" mix in 1997 and obtained a value of 0.304 calories/degree/ gram (equivalent to $1.27 \mathrm{~J} / \mathrm{g} /{ }^{\circ} \mathrm{C}$ ) [3]. The calculations using the simple law of mixtures and the measurements for specific heat presented in this report both reveal that the specific heat capacities of Saltstone mixes are greater than this previously reported value by $\sim 55 \%$. The $55 \%$ increase is significant in calculating the expected temperature rise of Saltstone in the SDF as will be detailed in the report.

The initial temperature of the Saltstone mixes in the Saltstone Production Facility (SPF) can be predicted using the specific heat capacities of Decontaminated Salt Solutions (DSS), the specific heat capacities of cementitious materials, and the initial temperatures of the DSS and the premix. An example of this approach is provided in this report and demonstrates the temperature of the initial mix is controlled mainly by the initial temperature of the salt solution.

\subsection{EXPERIMENTAL}

\subsection{Materials}

The cementitious materials were obtained from Saltstone in 5 gallon containers and are listed in Table 2-1. These materials were specified in a contract for Saltstone cementitious materials and arrived with the delivery of the cementitious materials to Saltstone. The materials were transferred to smaller plastic bottles at Aiken County Technology Laboratory (ACTL) and tightly sealed. Maintaining these materials in a tightly sealed container limits the exposure of the materials to humid air. Table $2-1$ also contains the wt $\%$ contribution of each material used to make the premix. 
Table 2-1 Saltstone Cementitious Materials

\begin{tabular}{|c|c|c|c|}
\hline Material & Category & Vendor & Premix Blend (wt\%) \\
\hline Portland cement (OPC) & Type II & Holcim & 10 \\
\hline Blast Furnace slag (GGBFS) & Grade I or II & Holcim & 45 \\
\hline Fly ash (FA) & Class F & SEFA & 45 \\
\hline
\end{tabular}

The compositions of DDA, MCU and SWPF simulants have been detailed elsewhere [2].

\subsection{Measurement of Specific Heat Capacity}

A method was developed for the measurement of $C_{p}$ using the heat flow sensing capability of the TAM Air Isothermal Calorimeter. Figure 2-1 shows the schematic of the twin cell calorimeter where both cells are maintained at a selected temperature (for these experiments, the temperature was set at $25^{\circ} \mathrm{C}$ ). Under normal operation for measurement of the heat of hydration, the sample ampoule is loaded with a fresh grout mix, placed in the sample channel, and the heat flow to the primary heat sink detected by the differential heat flow signal (using Seebeck sensors) between the sample and reference ampoules.

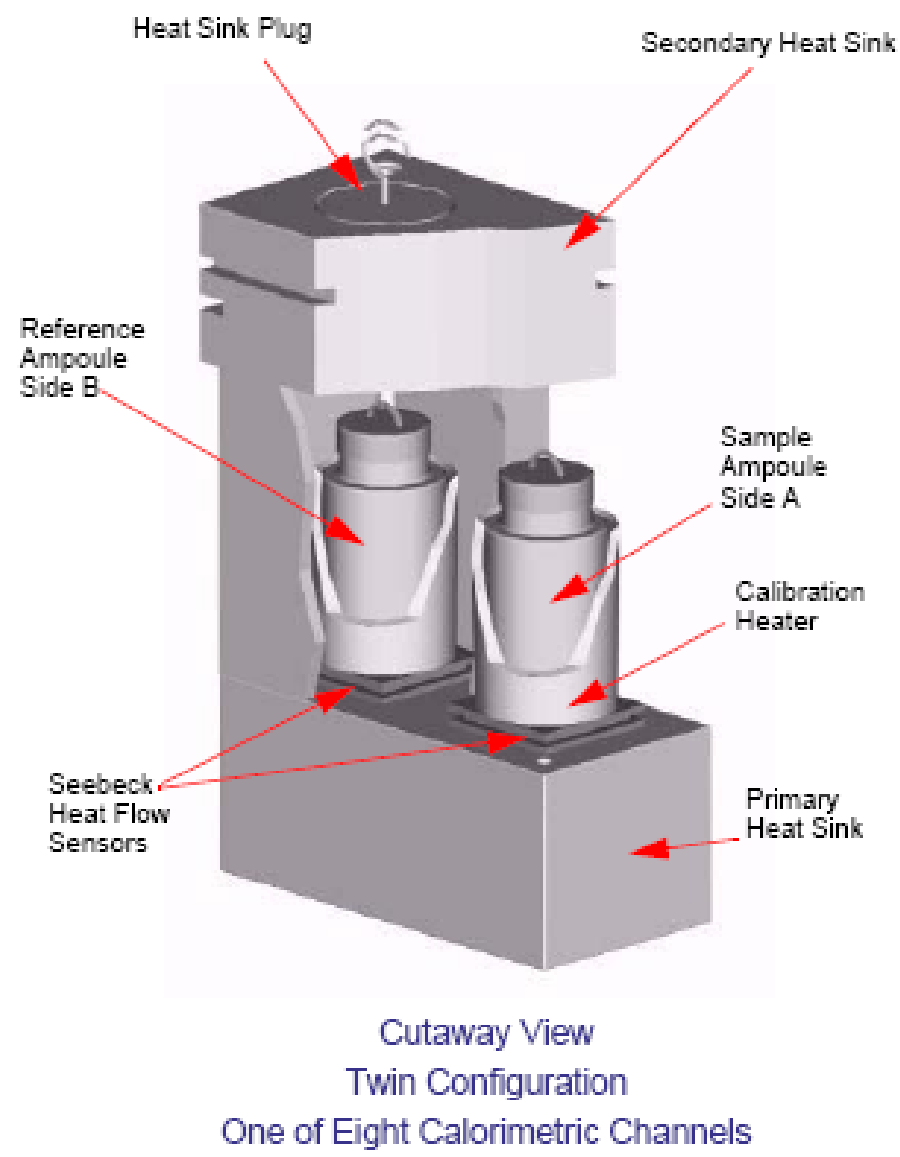

Figure 2-1 Cutaway view of the twin configuration TAM Air Isothermal Calorimeter 
Normally, the temperature of the grout mix introduced into the sample ampoule is different from the $25{ }^{\circ} \mathrm{C}$ temperature of the bath. For this reason, there is a 45 minute period in which thermal equilibration is established prior to initiating data collection. Although the hydration data for this 45 minute period is not captured, the amount of heat produced from cementitious materials hydration over this 45 minute period is generally not significant compared to the total heat generation over days or weeks.

The approach taken for measurement of $\mathrm{C}_{\mathrm{p}}$ in this study was to intentionally heat the sample in the sample ampoule to a known temperature, emplace the ampoule into the calorimeter, and then measure the heat flow as the sample thermally equilibrates. The integral of the heat flow gives the total heat in Joules released from the sample ampoule. For example, an ampoule with 20 grams of water was heated to $35^{\circ} \mathrm{C}$ and immediately placed within the calorimeter. The amount of heat flow measured from the sample ampoule to the calorimeter during the equilibration phase will equal the amount of heat required to raise 20 grams of water $10{ }^{\circ} \mathrm{C}$ above the set temperature of $25^{\circ} \mathrm{C}$. The specific heat capacity for water can then be calculated from the total heat transferred (after subtracting the amount of heat associated with the empty plastic ampoule) by dividing first by 20 (number of grams) and then by 10 (number of ${ }^{\circ} \mathrm{C}$ ).

Experiments were performed to measure the $\mathrm{C}_{\mathrm{p}}$ of water using different amounts of water and different final temperatures to which the sample was heated. Testing showed that heating the sample to a temperature of $35^{\circ} \mathrm{C}$ and introducing a mass of water equal to $\sim 10$ grams provided reasonable experimental conditions as well as excellent results for $\mathrm{C}_{\mathrm{p}}$ of water $\left(4.11 \mathrm{~J} / \mathrm{g} /{ }^{\circ} \mathrm{C}\right.$ measured vs. the literature reference value of $4.18 \mathrm{~J} / \mathrm{g} /{ }^{\circ} \mathrm{C}$ ).

A standard was selected with a $\mathrm{C}_{\mathrm{p}}$ value relatively close to that expected for the Saltstone mixes that would be measured each time a series of samples are measured. There are eight channels available on the TAM Air calorimeter. Therefore, a maximum of 8 samples can be run at the same time depending upon other ongoing experiments with the calorimeter. Ethanol was selected as the standard with a known $\mathrm{C}_{\mathrm{p}}$ of $2.44 \mathrm{~J} / \mathrm{g} /{ }^{\circ} \mathrm{C}$. An example of the response for ethanol is provided in Figure 2-2. The heat flow curve shows an immediate flow of heat from the sample ampoule to the calorimeter heat sink which peaks after several minutes and then continues to decrease until thermal equilibration is reached (in this case a time of $\sim 45$ minutes). The response time constant of the calorimeter is on the order of several minutes so the kinetics of the actual heat flow are not accurately captured in this test. However, the integral of the heat flow, the thermodynamic total amount of heat released, is captured accurately and it is this value that is used for measurement of $\mathrm{C}_{\mathrm{p}}$.

In Figure 2-2, the total amount of heat released during thermal equilibration was $320.2 \mathrm{~J}$. The amount of heat released from the empty ampoule was $56.8 \mathrm{~J}$ such that $263.4 \mathrm{~J}$ were released from the 10.77 grams of ethanol in the ampoule. Therefore the $\mathrm{C}_{\mathrm{p}}$ for ethanol is calculated by dividing $263.4 \mathrm{~J}$ first by $10.77 \mathrm{~g}$ of ethanol and then by $10^{\circ} \mathrm{C}$ to obtain $2.44 \mathrm{~J} / \mathrm{g} /{ }^{\circ} \mathrm{C}$. Values obtained for ethanol in the experiments reported in this work ranged from 2.35 to $2.45 \mathrm{~J} / \mathrm{g} /{ }^{\circ} \mathrm{C}$. 


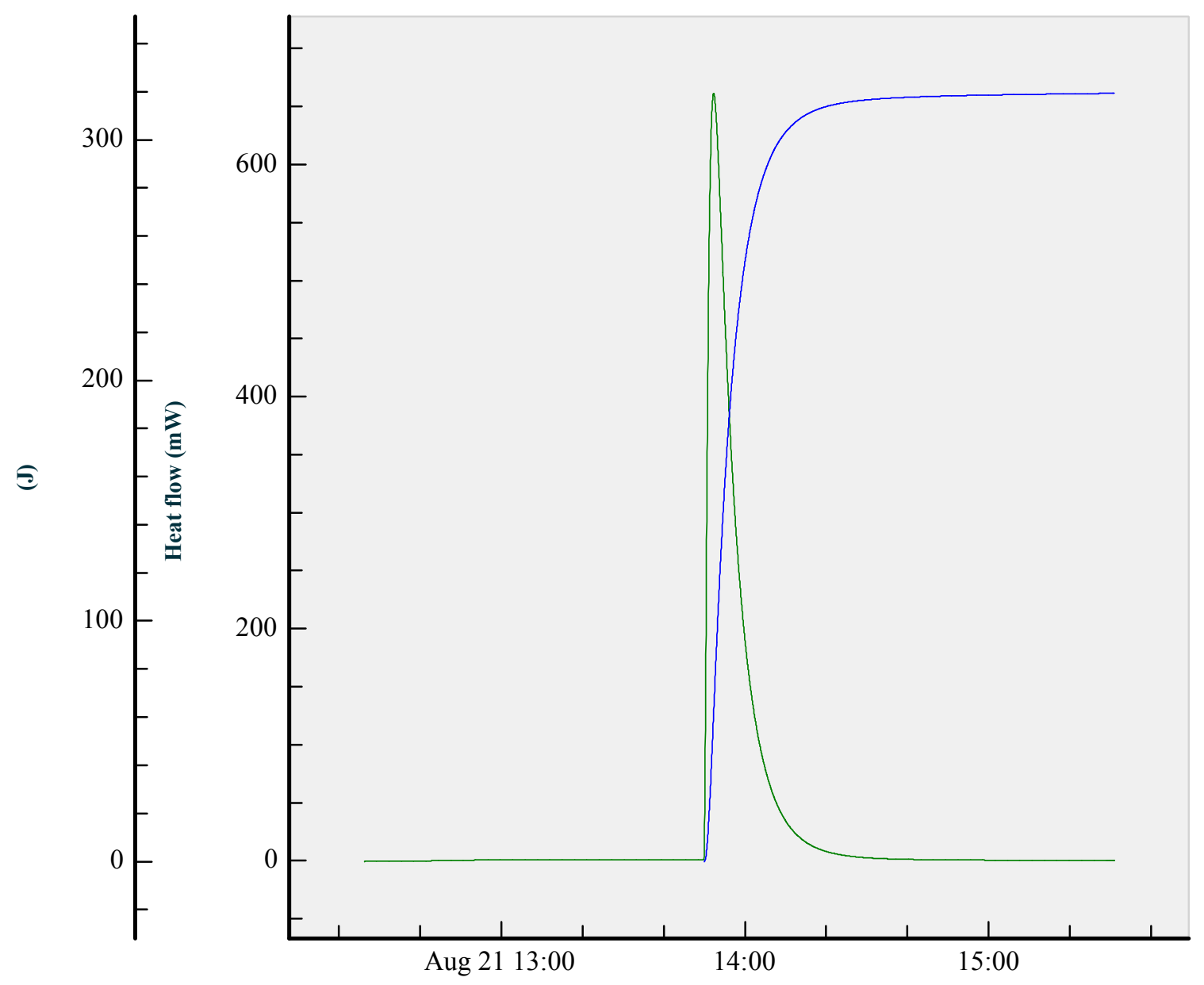

Figure 2-2 The time dependence of heat flow and heat for $10.77 \mathrm{~g}$ of ethanol in the sample ampoule

The method for measurement of $\mathrm{C}_{\mathrm{p}}$ is provided below.

1. Add known mass of material to be measured into sample ampoule

2. Heat sample ampoule in water bath to $35.3{ }^{\circ} \mathrm{C}$ (Since heat is lost during step 3 , the actual temperature of the water bath was set at $35.3^{\circ} \mathrm{C}$ to meet the target of $35^{\circ} \mathrm{C}$ )

3. Quickly $(<10$ seconds) place heated sample ampoule in calorimeter

4. Measure heat release until thermal equilibration is reached ( $\sim 1$ to 2 hours)

5. Subtract heat associated with empty container only (this average value is $56.8 \mathrm{~J}$ )

6. Divide total net heat by mass of the material and by $10(\Delta \mathrm{T})$

7. The result is the specific heat capacity in $\mathrm{J} / \mathrm{g} /{ }^{\circ} \mathrm{C}$

8. Ensure that the value of $\mathrm{C}_{\mathrm{p}}$ for the ethanol standard is within the range of 2.35 to 2.45 $\mathrm{J} / \mathrm{g} /{ }^{\circ} \mathrm{C}$ 


\subsection{RESULTS AND DISCUSSION}

\subsection{Specific Heat Capacity of Saltstone Cementitious Materials and Simulants}

In order the predict the $\mathrm{C}_{\mathrm{p}}$ of Saltstone mixes using the simple law of mixtures, it was first necessary to measure the $C_{p}$ 's of the cementitious materials and the simulants used to batch these Saltstone mixes. The results are presented in Table 3.1.

Table 3-1 Measured Specific Heat Capacities for Saltstone Simulants and Cementitious Materials

\begin{tabular}{|c|c|c|}
\hline MATERIAL & Measured $\mathrm{C}_{\mathrm{p}}$ & Literature $\mathrm{C}_{\mathrm{p}}$ \\
\hline & $\mathrm{J} / \mathbf{g} /{ }^{\circ} \mathrm{C}$ & $\mathrm{J} / \mathbf{g} /{ }^{\circ} \mathrm{C}$ \\
\hline REFERENCE & & \\
\hline Water & 4.11 & 4.18 \\
\hline STANDARD & & \\
\hline Ethanol & $2.35-2.45$ & 2.44 \\
\hline CEMENTITIOUS MATERIALS & & \\
\hline OPC & 0.73 & $\sim 0.8$ \\
\hline BFS & 0.78 & Unknown \\
\hline Class F FA & 0.78 & Unknown \\
\hline SIMULANTS & & \\
\hline DDA & 3.48 & Unknown \\
\hline MCU & 3.31 & Unknown \\
\hline SWPF & 3.36 & Unknown \\
\hline
\end{tabular}

The measured value of $\mathrm{C}_{\mathrm{p}}$ for the reference water sample of $4.11 \mathrm{~J} / \mathrm{g} /{ }^{\circ} \mathrm{C}$ was in excellent agreement with the literature value of $4.18 \mathrm{~J} / \mathrm{g} /{ }^{\circ} \mathrm{C}[8]$. The $\mathrm{C}_{\mathrm{p}}$ values for ethanol used as the standard ranged from 2.35 to $2.45 \mathrm{~J} / \mathrm{g} /{ }^{\circ} \mathrm{C}$, again in excellent agreement with the literature value of $2.44 \mathrm{~J} / \mathrm{g} /{ }^{\circ} \mathrm{C}[8]$.

The composite $\mathrm{C}_{\mathrm{p}}$ of the nominal premix (45\% Blast Furnace Slag (BFS), $45 \%$ Fly Ash (FA) and $10 \%$ Ordinary Portland Cement (OPC)) was calculated by multiplying the mass fraction of each cementitious material by the corresponding $\mathrm{C}_{\mathrm{p}}$ for each component and then summing the three components. This leads to a composite $\mathrm{C}_{\mathrm{p}}$ for the premix of $0.78 \mathrm{~J} / \mathrm{g} /{ }^{\circ} \mathrm{C}$.

The presence of high levels of dissolved salts in the simulants (which is also the case for the radioactive DSS) reduces the $\mathrm{C}_{\mathrm{p}}$ 's of the solutions by approximately $17 \%$ relative to water. In general, the $\mathrm{C}_{\mathrm{p}}$ 's of salt solutions decrease with increasing salt concentration. This trend was observed for the three simulants with DDA containing the lowest concentration of salts and MCU containing the highest concentration of salts. 


\subsection{Prediction of Specific Heat Capacity of Saltstone Mixes}

The $\mathrm{C}_{\mathrm{p}}$ 's for Saltstone grouts were predicted using the simple law of mixtures. Using Equation 1 , the $C_{p}$ values for Saltstone grouts were predicted for each of the three simulants (DDA, MCU, and SWPF) at a $0.60 \mathrm{w} / \mathrm{cm}$ ratio and the results are provided in Table 3-2. The measured values for these three mixes are also provided in Table 3-2 and are in excellent agreement with the predicted values.

Table 3-2 Predicted vs. Measured $C_{p}$ for the Three Saltstone Mixes

\begin{tabular}{|c|c|c|c|c|c|c|c|}
\hline Simulant & $\mathrm{C}_{\mathrm{p}}$ & Mass & Cementitious & $\mathrm{C}_{\mathrm{p}}$ & Mass & Predicted $\mathrm{C}_{\mathrm{p}}$ & Measured $\mathrm{C}_{\mathrm{p}}$ \\
\hline & $\mathrm{J} / \mathrm{g} /{ }^{\circ} \mathrm{C}$ & Fraction & Material & $\mathrm{J} / \mathrm{g} /{ }^{\circ} \mathrm{C}$ & Fraction & $\mathrm{J} / \mathrm{g} /{ }^{\circ} \mathrm{C}$ & $\mathrm{J} / \mathrm{g} /{ }^{\circ} \mathrm{C}$ \\
\hline DDA & 3.48 & 0.436 & Premix & 0.78 & 0.564 & 1.95 & 1.95 \\
\hline MCU & 3.31 & 0.467 & Premix & 0.78 & 0.533 & 1.96 & 1.94 \\
\hline SWPF & 3.36 & 0.458 & Premix & 0.78 & 0.542 & 1.96 & 1.96 \\
\hline
\end{tabular}

These $C_{p}$ values are considerably higher than the value of $1.25 \mathrm{~J} / \mathrm{g} /{ }^{\circ} \mathrm{C}$ reported in 1997 for the Saltstone mix prepared using the "reference Saltstone" formulation [3]. As discussed later, the higher values of $\mathrm{C}_{\mathrm{p}}$ measured in this report lead to significant differences in the predicted temperature changes in the Saltstone Vaults when using isothermal heats of hydration and the newly measured $\mathrm{C}_{\mathrm{p}}$ 's.

\subsection{Impact of $w / c m$ Ratio on the Predicted and Measured $\mathrm{C}_{\mathrm{p}}$ 's}

The impact of $\mathrm{w} / \mathrm{cm}$ ratio on the $\mathrm{C}_{\mathrm{p}}$ was determined for SWPF mixes at $0.45,0.60$ and $0.65 \mathrm{w} / \mathrm{cm}$ ratios. The predicted and the measured values for $C_{p}$ are presented in Table 4-3 and again are in excellent agreement.

Table 3-3 Predicted Vs. Measured $C_{p}$ for the SWPF Mix at Different w/cm Ratios

\begin{tabular}{|c|c|c|c|c|c|c|c|c|}
\hline w/cm & Simulant & $\mathrm{C}_{\mathrm{p}}$ & Mass & Cementitious & $\mathrm{C}_{\mathrm{p}}$ & Mass & Predicted $\mathrm{C}_{\mathrm{p}}$ & ${\text { Measured } \mathrm{C}_{\mathrm{p}}}$ \\
\hline & & $\mathrm{J} / \mathrm{g} /{ }^{\circ} \mathrm{C}$ & Fraction & Material & $\mathrm{J} / \mathrm{g} /{ }^{\circ} \mathrm{C}$ & Fraction & $\mathrm{J} / \mathrm{g} /{ }^{\circ} \mathrm{C}$ & $\mathrm{J} / \mathrm{g} /{ }^{\circ} \mathrm{C}$ \\
\hline 0.45 & SWPF & 3.36 & 0.388 & Premix & 0.78 & 0.612 & 1.78 & 1.81 \\
\hline 0.60 & SWPF & 3.36 & 0.458 & Premix & 0.78 & 0.542 & 1.96 & 1.96 \\
\hline 0.65 & SWPF & 3.36 & 0.478 & Premix & 0.78 & 0.522 & 2.01 & 2.05 \\
\hline
\end{tabular}

The magnitude of the predicted range from 1.78 to $2.01 \mathrm{~J} / \mathrm{g} /{ }^{\circ} \mathrm{C}$ is significant and demonstrates that higher $\mathrm{w} / \mathrm{cm}$ ratios will lead to higher heat capacities and correspondingly lower temperature increases in grout mixes for a given heat of hydration value. Conversely, as new formulations are developed to improve performance properties, the $\mathrm{w} / \mathrm{cm}$ ratio may decrease which in turn will increase the temperature in the vault for a given heat of hydration. Figure 3-1 shows the predicted dependency of $\mathrm{C}_{\mathrm{p}}$ on $\mathrm{w} / \mathrm{cm}$ ratio using the simple law of mixtures. 


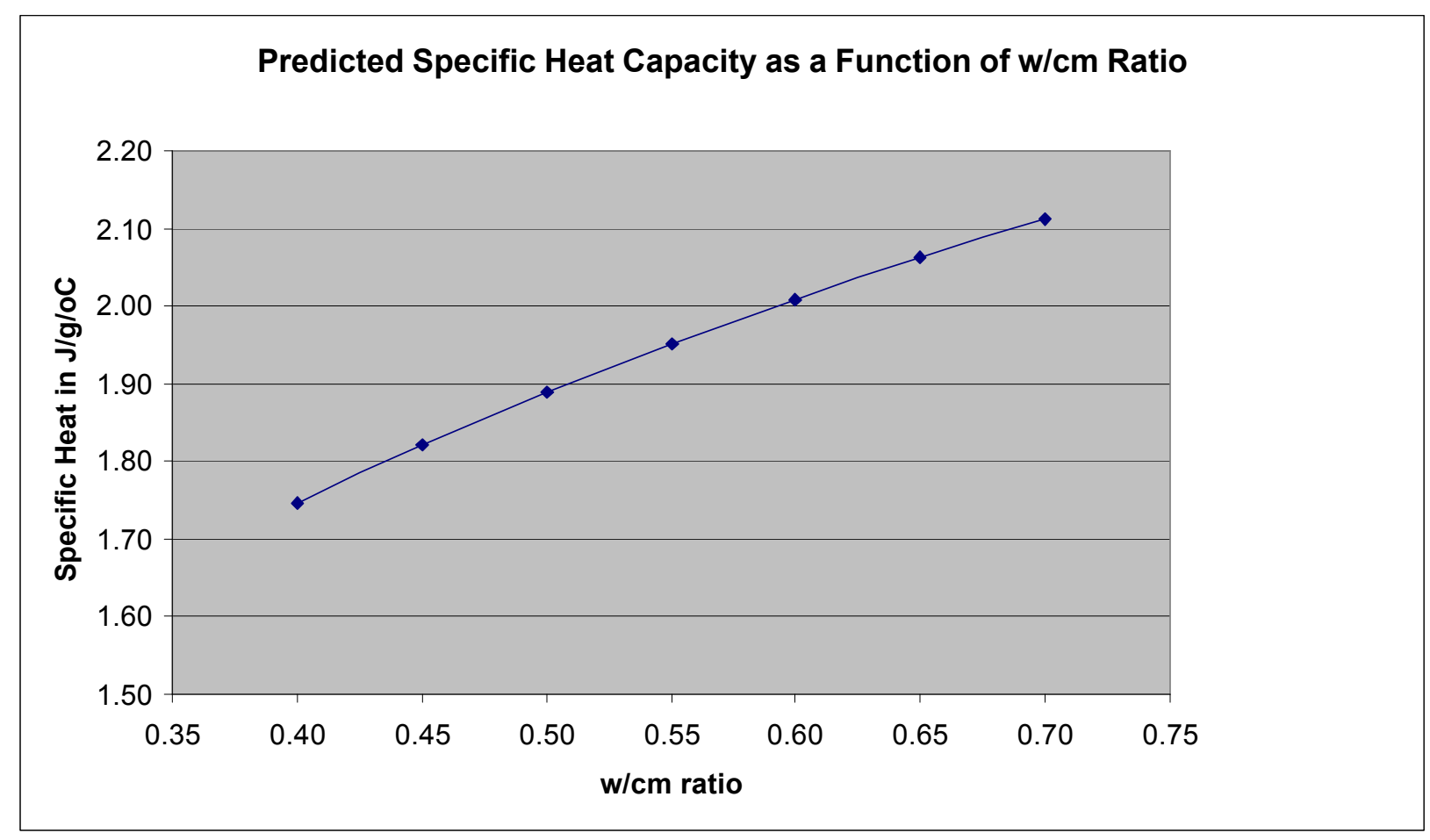

Figure 3-1 Predicted dependence of $C_{p}$ on w/cm ratio for SWPF mixes based on simple law of mixtures

\subsection{Time Dependence of $\mathbf{C}_{\mathrm{p}}$}

The predicted heat capacities using the simple law of mixtures correspond to the freshly prepared grout mixes immediately after mixing. For example, in the case of OPC in water mixes, the prediction of $\mathrm{C}_{\mathrm{p}}$ corresponds well with the initial measurement [7]. However, the $\mathrm{C}_{\mathrm{p}}$ then decreases slightly with time as the hydration reactions of OPC take place. Although there is significant variation in the results from different laboratories, in general, the reduction in heat capacity is on the order of 10 to $20 \%$ [7]. Thus, it was important to determine the magnitude of change in $\mathrm{C}_{\mathrm{p}}$ as a function of time for Saltstone mixes.

In order to determine the change in $\mathrm{C}_{\mathrm{p}}$ as a function of curing time for Saltstone mixes, an MCU mix at $0.60 \mathrm{w} / \mathrm{cm}$ ratio was batched and the $C_{p}$ measured as a function of time. During the early stages of hydration, the heat of hydration contributed to the signal used to measure the $C_{p}$. Therefore, a subtraction of the amount of heat generated by the hydration reactions over the time span of the measurement (typically between 1 to 1.5 hours and with values in the range of 10 to $30 \mathrm{~J}$ ) was performed to correct the value of heat capacity. The results of the time dependence test are provided as a graph in Figure 3-2 and show that the $\mathrm{C}_{\mathrm{p}}$ does not change significantly as a function of time (the $>90$ day $\mathrm{C}_{\mathrm{p}}$ of $\mathrm{MCU}$ mix included in the Figure $3-2$ was $1.98 \mathrm{~J} / \mathrm{g} /{ }^{\circ} \mathrm{C}$ as measured on an equivalent but different batch of MCU/premix grout). 


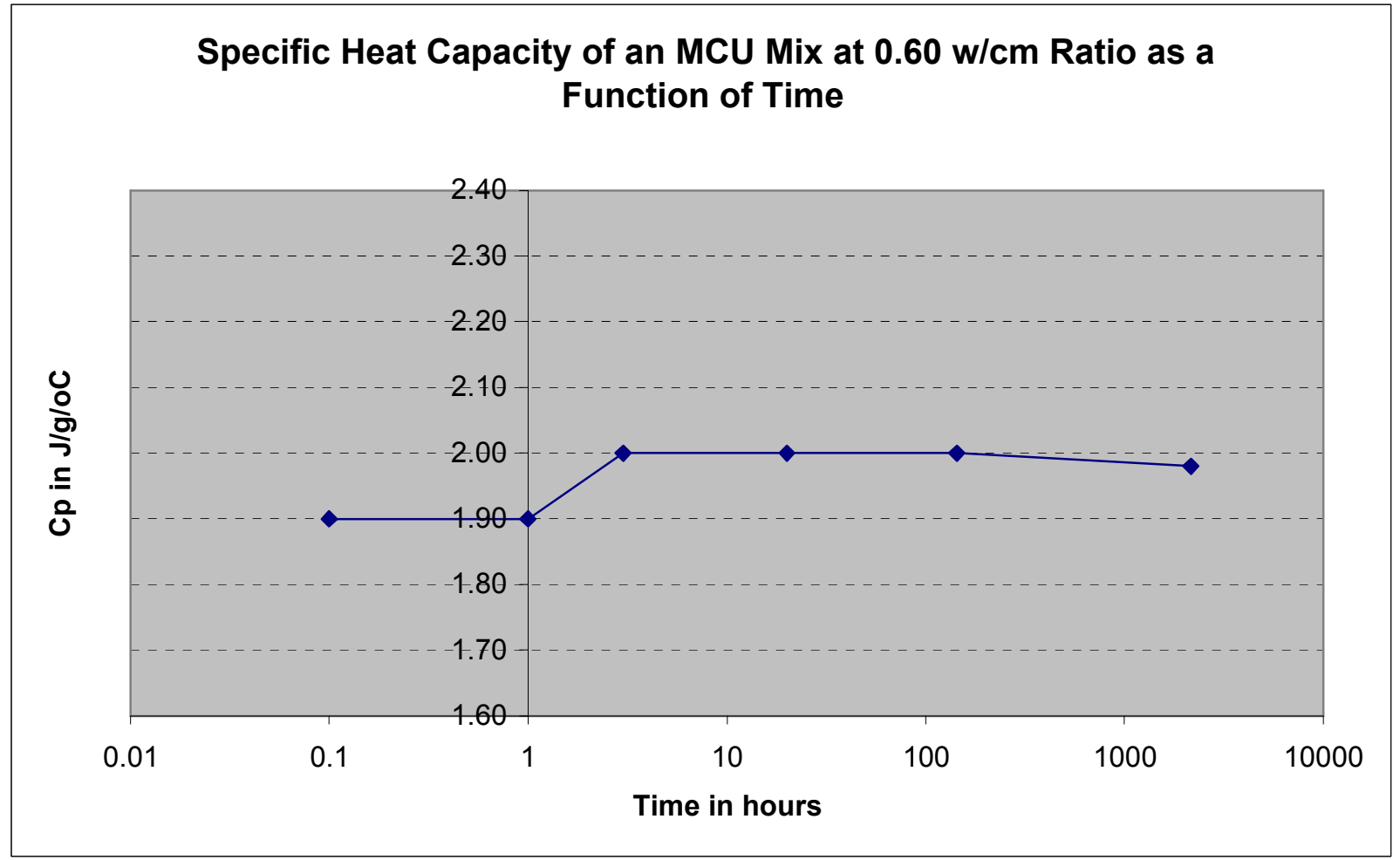

Figure 3-2 Time dependence (logarithmic) of $\mathrm{C}_{\mathrm{p}}$ for an $\mathrm{MCU}$ mix at $0.60 \mathrm{w} / \mathrm{cm}$ ratio

The fact that the $\mathrm{C}_{\mathrm{p}}$ does not decrease with time as observed with OPC in water mixes may be due in part to the fact that the degree of hydration in Saltstone mixes is only 30 to 40 percent compared to $\sim 100 \%$ degree of reaction observed with OPC water mix.

\subsection{Impact of Aluminate on $\mathbf{C}_{\mathrm{p}}$}

It has previously been demonstrated that the presence of aluminate ions in the salt solution increased the amount of heat generated per gram of grout sample [9]. Because the temperature increase for Saltstone in the vaults will also depend on the $\mathrm{C}_{\mathrm{p}}$, it is also important to determine the dependence of $\mathrm{C}_{\mathrm{p}}$ as a function of aluminate concentration. Table 3-4 presents this data and shows that the measured and predicted values of heat capacity do not change over the aluminate concentration range covered in these tests. 
Table 3-4 Predicted Vs. Measured $C_{p}$ as a Function of Aluminate Molarity

\begin{tabular}{|c|c|c|c|c|c|c|c|c|}
\hline Aluminate & Simulant & $\mathrm{Cp}$ & Mass & Cementitious & $\mathrm{Cp}$ & Mass & Predicted Cp & Measured Cp \\
\hline $\mathrm{M}$ & & $\mathrm{J} / \mathrm{g} /{ }^{\circ} \mathrm{C}$ & Fraction & Material & $\mathrm{J} / \mathrm{g} /{ }^{\circ} \mathrm{C}$ & Fraction & $\mathrm{J} / \mathrm{g} /{ }^{\circ} \mathrm{C}$ & $\mathrm{J} / \mathrm{g} /{ }^{\circ} \mathrm{C}$ \\
\hline 0.11 & SWPF & 3.36 & 0.458 & Premix & 0.78 & 0.542 & 1.96 & 1.91 \\
\hline 0.22 & SWPF & 3.36 & 0.461 & Premix & 0.78 & 0.539 & 1.97 & 1.86 \\
\hline 0.33 & SWPF & 3.36 & 0.464 & Premix & 0.78 & 0.536 & 1.97 & 1.91 \\
\hline 0.44 & SWPF & 3.36 & 0.467 & Premix & 0.78 & 0.533 & 1.98 & 1.91 \\
\hline
\end{tabular}

\subsection{Maximum Temperature Increase}

The $\mathrm{C}_{\mathrm{p}}$ and heat of hydration data (obtained from isothermal calorimetry) for a mix can be combined to calculate the adiabatic temperature increase of the mix. The adiabatic temperature increase is the maximum temperature increase of the grout that would result from the hydration reactions if there were no pathway for loss of heat from the grout. In that sense it is a conservative determination of the maximum temperature increase in the Saltstone Vaults. In practice, the heat of hydration and $\mathrm{C}_{\mathrm{p}}$ data are used as input into a model that accounts for heat losses and consequently, a more realistic temperature increase in the vaults [4].

Figure 3-3 shows the maximum temperature rise for a premix DDA mix at a $0.60 \mathrm{w} / \mathrm{cm}$ ratio. The starting temperature was assumed to be $25^{\circ} \mathrm{C}$. This graph was generated using heat of hydration data generated isothermally at $25^{\circ} \mathrm{C}$. At higher temperatures, the reactions occur at a faster initial rate but reach the same heat output up to $55^{\circ} \mathrm{C}$, which was the maximum temperature we tested with isothermal calorimetry.

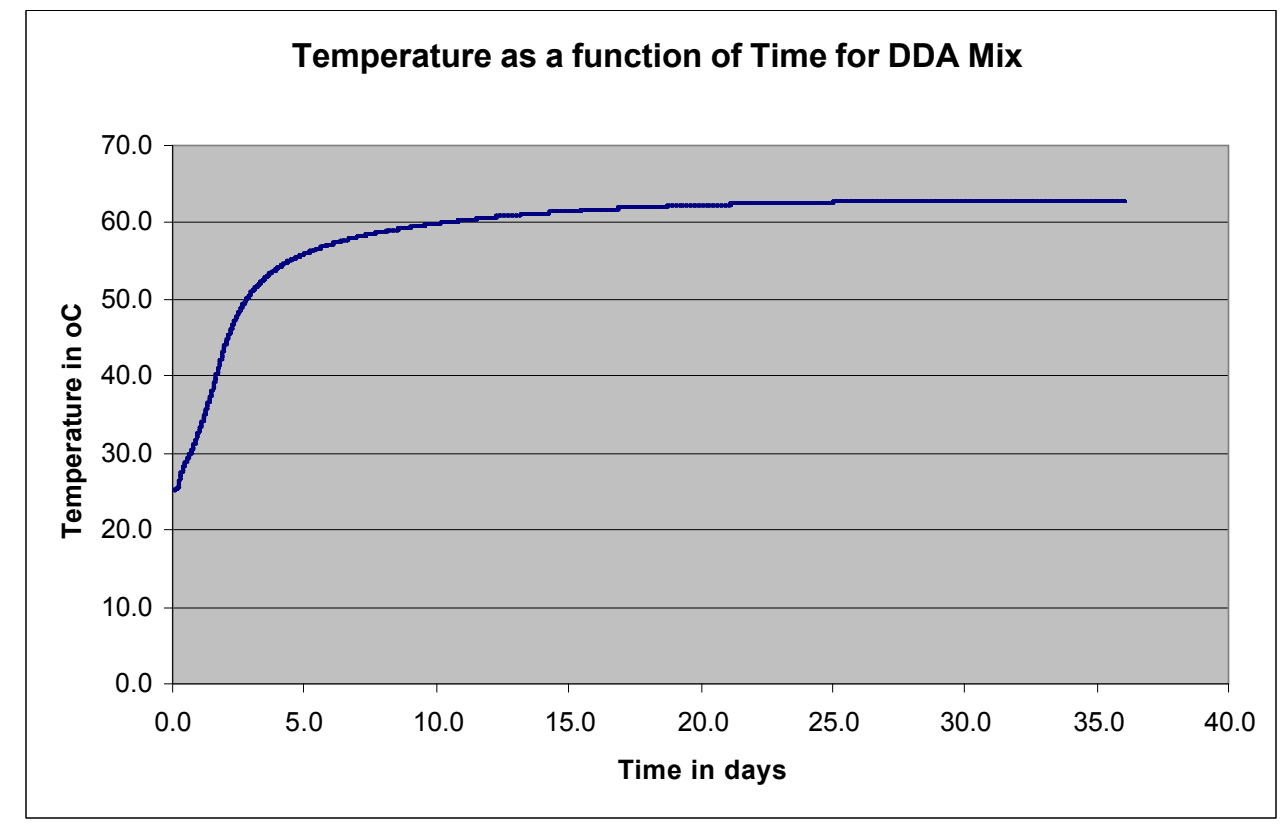

Figure 3-3 Calculated maximum temperature increase of DDA/premix mix at $0.60 \mathrm{w} / \mathrm{cm}$ ratio 
Figure 3-4 shows the maximum temperature reached for an OPC and water mix at a w/cm ratio of 0.60 for two different values of heat capacity, 2.05 and $1.80 \mathrm{~J} / \mathrm{g} /{ }^{\circ} \mathrm{C}$. As discussed earlier, the fresh paste for this mix has an initial $\mathrm{C}_{\mathrm{p}}$ of $2.05 \mathrm{~J} / \mathrm{g} /{ }^{\circ} \mathrm{C}$ which is reduced in value to $1.80 \mathrm{~J} / \mathrm{g} /{ }^{\circ} \mathrm{C}$ as it cures. Therefore, the two predicted curves bound the adiabatic temperature increase for this mix.

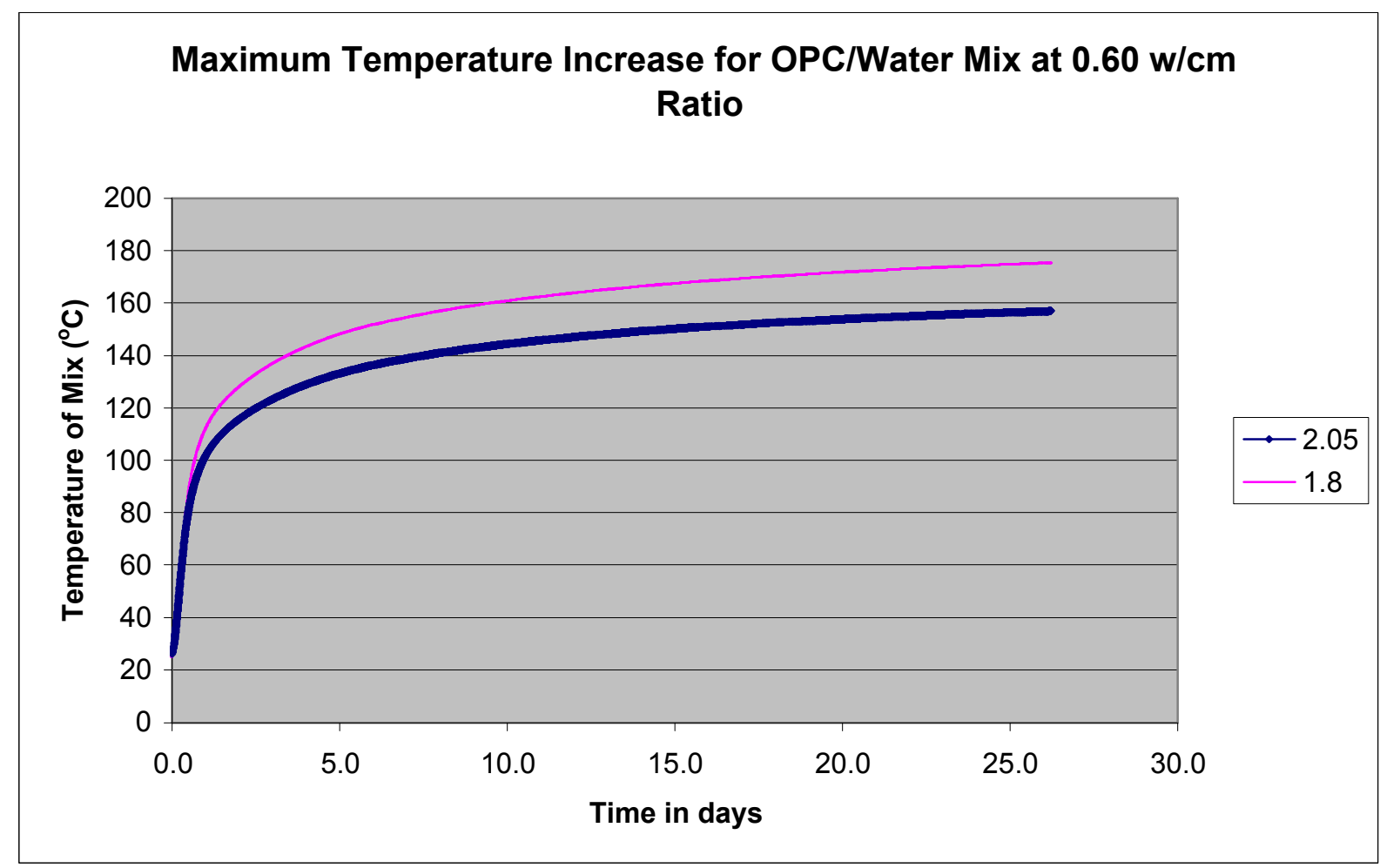

Figure 3-4 Calculated maximum temperature increase of water/OPC mix at $0.60 \mathrm{w} / \mathrm{cm}$ ratio for two different values of $C_{p}$

Figure 3-5 shows how the maximum temperature increase for a mix prepared with MCU simulant and BFS. This plot also shows the sensitivity of the predicted maximum temperature in the vault to variation in $\mathrm{C}_{\mathrm{p}}$. In this case the range of $\mathrm{C}_{\mathrm{p}}$ values selected was 1.80 to $2.0 \mathrm{~J} / \mathrm{g} /{ }^{\circ} \mathrm{C}$ and the corresponding maximum temperature ranged from 127 to $117^{\circ} \mathrm{C}$ (inverse correlation). When $100 \%$ BFS is mixed with MCU simulant, the heat of hydration of the resultant mix is significantly greater than a mix prepared with premix and MCU simulant. 


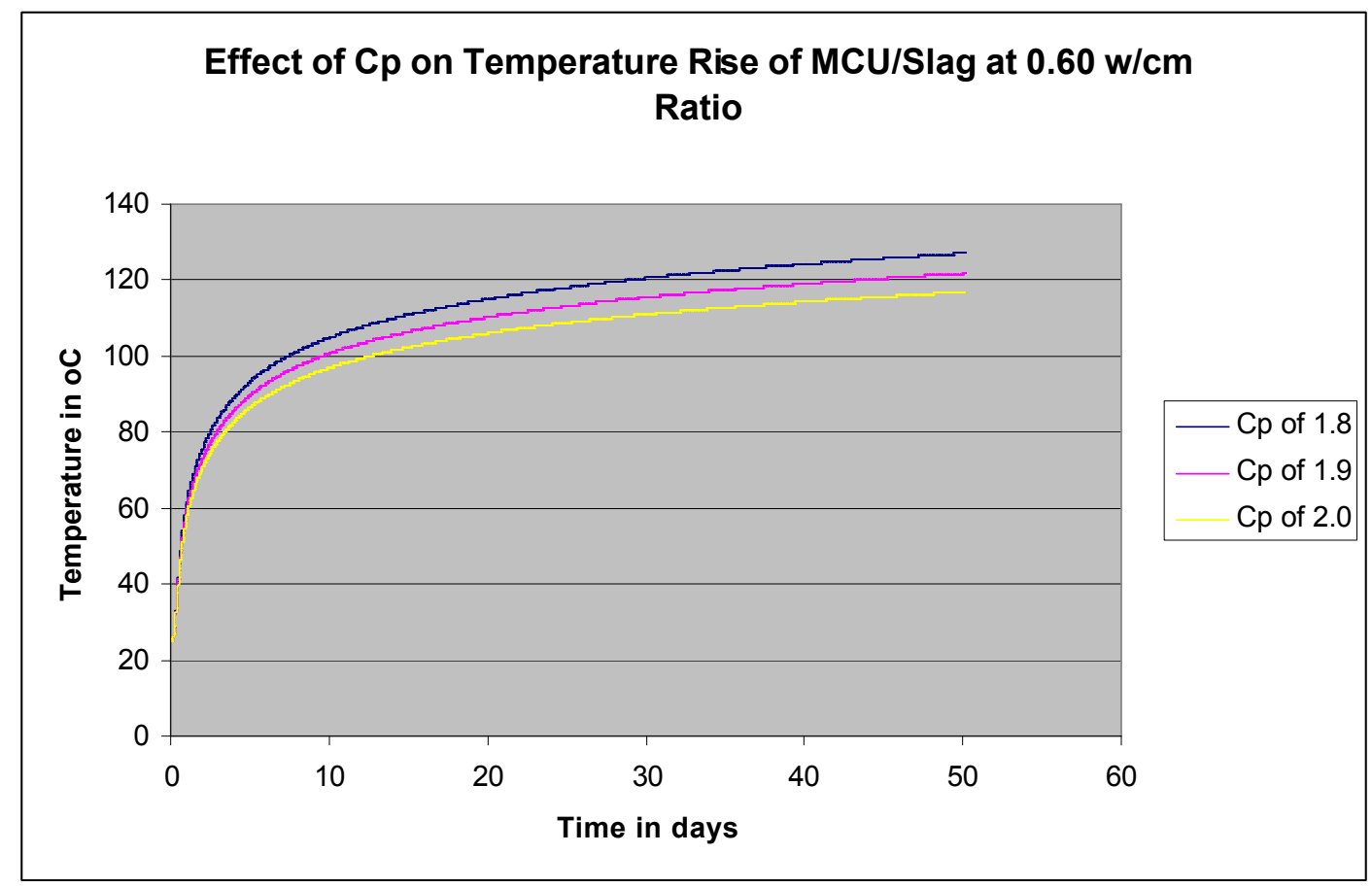

Figure 3-5 Calculated maximum temperature increase of MCU/BFS mix at $0.60 \mathrm{w} / \mathrm{cm}$ ratio using three different values for the specific heat capacity

Table 3-5 presents a summary of the results of the calculated maximum adiabatic temperatures for a variety of mixes. Both DDA and MCU mixes produce less heat than the SWPF mix. As previously reported, aluminate in SWPF mixes increases the final temperature of the mixes. The Delta $\mathrm{T}$ for each mix and a final temperature calculated based on an initial temperature of $25^{\circ} \mathrm{C}$ are provided in Table 3-5.

Table 3-5 Summary of Predicted Maximum Temperatures of Various Grout Mixes

\begin{tabular}{|c|c|c|c|c|c|c|c|}
\hline \multicolumn{7}{|c|}{ Isothermal Measurements and Predictions } \\
\hline Curing Time & Mix & w/cm & Heat & Cp & Delta T & Initial T & Final T \\
\hline days & & & $\mathrm{J} / \mathrm{g}$ & $\mathrm{J} / \mathbf{g} /{ }^{\circ} \mathrm{C}$ & ${ }^{\circ} \mathrm{C}$ & ${ }^{\circ} \mathrm{C}$ & ${ }^{\circ} \mathrm{C}$ \\
\hline 35 & DDA & 0.60 & 72 & 1.95 & 37 & 25 & 62 \\
\hline 45 & MCU & 0.60 & 80 & 1.95 & 41 & 25 & 66 \\
\hline 40 & SWPF & 0.60 & 94 & 1.95 & 48 & 25 & 73 \\
\hline 40 & SWPF/aluminate & 0.60 & 130 & 1.90 & 68 & 25 & 93 \\
\hline 50 & MCU/OPC & 0.60 & 187 & 1.85 & 101 & 25 & 126 \\
\hline 50 & MCU/BFS & 0.60 & 185 & 1.85 & 100 & 25 & 125 \\
\hline 32 & $\mathrm{H}_{2}$ O/OPC & 0.60 & 250 & 1.79 & 140 & 25 & 165 \\
\hline
\end{tabular}

These temperature increases can be compared to literature values obtained for Saltstone mixes by adiabatic calorimetry. The delta T measured by Steimke and Fowley [3] for the reference Saltstone mix is $72{ }^{\circ} \mathrm{C}$, a value reasonably close to the $68^{\circ} \mathrm{C}$ delta $\mathrm{T}$ predicted from isothermal 
measurements with SWPF and aluminate. Steimke and Fowley's reference Saltstone contained $0.33 \mathrm{M}$ aluminate, a component that has been shown to significantly increase the amount of heat generated in the mixes. Lokken also had a relatively high Delta $\mathrm{T}$ with his measurements at high aluminate concentrations [10]. Bollinger's value [11] is somewhat lower and was attributed by Steimke [3] to using cementitious materials which may have aged (partially hydrated) prior to mixing.

Table 3-6 Summary of Adiabatic Temperature Measurements from Literature

\begin{tabular}{|c|c|c|c|c|c|}
\hline \multicolumn{7}{|c|}{ Adiabatic Measurements } \\
\hline Source & w/cm & Aluminate & Delta T & Initial T & Final T \\
\hline & & $\mathbf{M}$ & ${ }^{\circ} \mathrm{C}$ & ${ }^{\circ} \mathrm{C}$ & ${ }^{\circ} \mathrm{C}$ \\
\hline Steimke and Fowley & 0.61 & 0.35 & 72 & 38 & 110 \\
\hline Bollinger & NA & 0.35 & 46 & 38 & 84 \\
\hline Lokken & 0.60 & 0.82 & 69 & 35 & 104 \\
\hline
\end{tabular}

\subsection{Prediction of Fresh Mix Temperature in the SPF}

The maximum temperature increase of Saltstone in the vaults obviously depends on the initial mix temperature in the SPF. This initial mix temperature can be calculated if the temperature and the specific heat capacities of the premix and the DSS are known. This report has provided the $\mathrm{C}_{\mathrm{p}}$ 's of the premix (and individual components) and the DSS simulants so, if the DSS and premix temperatures are known, the initial temperature of the mix can be predicted. For example, if the initial temperature of the DSS is $20^{\circ} \mathrm{C}$ and the premix is $40{ }^{\circ} \mathrm{C}$, the initial mix temperature is $24.3^{\circ} \mathrm{C}$. Thus, the temperature of the DSS, with its high $\mathrm{C}_{\mathrm{p}}$, is the major determinant of the initial mix temperature. 


\subsection{CONCLUSIONS}

Specific heat capacity is an important property of Saltstone mixes which along with the isothermally measured heat of hydration controls the maximum temperature increase of Saltstone in the vaults. The heat capacity, like other properties of Saltstone is dependent on the composition of the DSS, mix formulation, and operational variation. It is therefore, important to have an in house method available for measuring heat capacity accurately, quickly and inexpensively for the variability study where a large number of samples will be generated and tested.

Conclusions from this study are:

- A method was developed and implemented for measurement of the specific heat capacity of Saltstone mixes and components (DSS simulants and cementitious materials)

- Heat capacities of Saltstone mixes were $~ 55 \%$ higher than a previous measurement on a reference Saltstone mix in 1997 [3]. Values of mixes prepared using DDA, MCU and $\mathrm{SWPF}$ simulants and premix at $0.60 \mathrm{w} / \mathrm{cm}$ ratio were $\sim 1.95 \mathrm{~J} / \mathrm{g} /{ }^{\circ} \mathrm{C}$ and were equivalent within experimental error.

- The simple law of mixtures was used to predict the heat capacities of the Saltstone and the results were in excellent agreement with experimental data. This simple law of mixtures can therefore be used to predict the heat capacities in those cases where measurements have not been made.

- The $\mathrm{w} / \mathrm{cm}$ ratio plays a key role in determining the value of the heat capacity. Both experimental and predictive values for SWPF as function of $\mathrm{w} / \mathrm{cm}$ were obtained and presented.

- The time dependence of the heat capacity is important as an input to the modeling of temperature increase in Saltstone vaults. The heat capacity of a mix of MCU and premix at $0.60 \mathrm{w} / \mathrm{cm}$ ratio was measured immediately after initial mixing and then periodically up to times greater than 100 days. Within experimental error, the heat capacity did not change with time.

- Maximum predicted temperatures of the Saltstone mixes were made using the heat of hydration data and the heat capacity for DDA, MCU and SWPF mixes. The temperature increase ranged from 37 to $48{ }^{\circ} \mathrm{C}$ for these mixes.

- Aluminate at $0.33 \mathrm{M}$ revealed a temperature increase of $68^{\circ} \mathrm{C}$ which is close to the adiabatic temperature rise of $74^{\circ} \mathrm{C}$ observed by Steimke and Fowler in 1997 for a mix containing $0.35 \mathrm{M}$ aluminate [3].

- Aluminum dissolution of the sludge will increase the aluminate in the DSS which in turn will result in a larger temperature increase in the Saltstone vaults.

- The measurement of specific heat capacities of DSS simulants and the cementitious materials allows for calculation of the initial temperature of the mix knowing the initial temperatures of the DSS and the premix. Controlling the initial temperature of the mix to lower temperatures will lead to lower maximum temperatures in the vault 


\subsection{PATH FORWARD}

A second important input into the model used for predicting temperature increase in the Saltstone Vaults is the thermal conductivity $(\mathrm{k})$. The loss of heat from Saltstone in the vault depends on thermal conductivity with greater values of $\mathrm{k}$ leading to greater rates of heat loss. Preliminary analysis indicates that the values of $\mathrm{k}$ for the Saltstone mixes most likely are within the range of 0.75 to $1.0 \mathrm{~W} / \mathrm{m}-{ }^{\circ} \mathrm{C}$. The current value used in the modeling effort at $\mathrm{SRS}$ is $1.0 \mathrm{~W} / \mathrm{m}-{ }^{\circ} \mathrm{C}$ as determined by Steimke and Fowley in 1997 [3]. A sensitivity study of the Vault temperature model over this range of $\mathrm{k}$ would reveal whether or not new measurements of $\mathrm{k}$ should be performed for grout formulations. Similarly, a sensitivity study to changes in heat of hydration data (in this case both the heat produced and the $\mathrm{C}_{\mathrm{p}}$ ) is also important.

\subsection{REFERENCES}

[1] Scoping Studies for Development of Saltstone Variability Study, J. R. Harbour and T. B. Edwards, WSRC-RP-2005-01439, Rev. 0, 2005.

[2] Variability Study for Saltstone, J. R. Harbour, T. B. Edwards, E. K. Hansen and V. J. Williams, WSRC-TR-2005-00447, October 2005.

[3] Measurement of Thermal Properties of Saltstone, J. L. Steimke and M. D. Fowley, WSRC-TR-97-00357, 1997.

[4] Saltstone Pour: A Thermal Model of Saltstone Pouring Process, M. A. Shadday, WSRCSTI-2007-00181, May, 2007.

[5] Controlling Temperatures in Mass Concrete, J. Gajda and M. Vangeem, Concrete International, page 59, January, 2002.

[6] Heat of Hydration of Saltstone Mixes - Measurement by Isothermal Calorimetry, J. R. Harbour, V. J. Williams and T. B. Edwards, WSRC-STI-2007-00263, Rev. 0, 2007.

[7] Transient Plane Source Measurements of the Thermal Properties of Hydrating Cement Pastes, D. P. Bentz, Materials and Structures, 40: (2007).

[8] Handbook of Chemistry and Physics, $58^{\text {th }}$ Edition, 1977-78.

[9] Effect of Increased Aluminate Concentrations on Saltstone Mixes, J. R. Harbour, T. B. Edwards, E. K. Hansen and V. J. Williams, WSRC-STI-2007-00506, Rev. 0, 2007.

[10] Characterization of Double-Shell Slurry Feed Grout Produced in a Pilot Scale Test, R. O. Lokken, PNL-7979. Rev. 0, 1992.

[11] Reference Saltstone Heat of Hydration Scoping Calorimetric Measurements, J. S. Bollinger, WSRC-TR-96-0103, Rev. 0, 1996. 